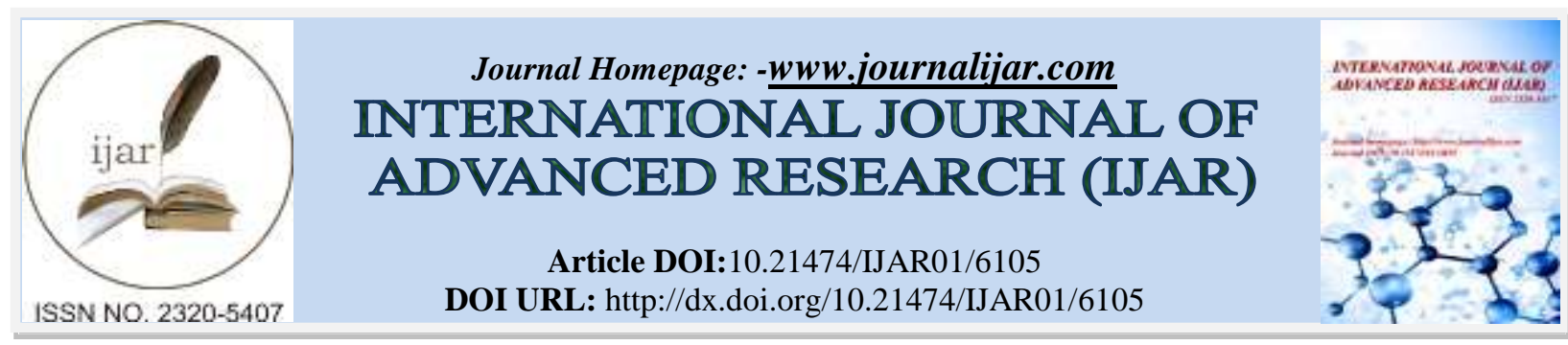

RESEARCH ARTICLE

\title{
RECOVERY OF URANIUM AND ASSOCIATED ELEMENTS FROM FERRUGINOUS GIBBSITE- BEARING SHALE OF DABBET ABU THOR LOCALITY, SW SINAI, EGYPT.
}

\author{
Enass M. El-Sheikh' ${ }^{1}$ Ibrahim E. El Aassy ${ }^{1}$, Adel A.-H. Abdel-Rahman', Mohamed I. Ayad², Wael M. Fathy ${ }^{3}$, \\ Mohamed N. Taha ${ }^{1}$ and Walaa A. Kassab ${ }^{1}$. \\ 1. Nuclear Materials Authority, P.O. Box 530 El Maadi, Cairo, Egypt. \\ 2. Chemistry department-faculty of Science- Minoufia University. \\ 3. Engineering faculty, Al-Azher University.
}

\section{Manuscript Info}

[........................

Manuscript History

Received: 19 October 2017

Final Accepted: 20 November 2017

Published: December 2017

Key words:-

Recovery, U, REEs, $\mathrm{Cu}, \mathrm{Zn}$, gibbsite.

\section{Abstract}

Chemical processing of the ferruginous gibbsite-bearing shale ore material of southwestern (SW) Sinai, has been studied for the recovery of $\mathrm{U}, \mathrm{REEs}$ and $\mathrm{B}$ together with the possible associated $\mathrm{Cu}, \mathrm{Zn}$ and $\mathrm{Al}$ contents. A technological sample assaying $0.04 \% \mathrm{U}, 0.2143 \%$ REEs, $1 \% \mathrm{Zn}, 2.3 \% \mathrm{Cu}, 38 \% \mathrm{Al}_{2} \mathrm{O}_{3}$ and $0.1 \% \mathrm{~B}$ has thus been collected. $\mathrm{U}$, REEs, $\mathrm{Cu}, \mathrm{Zn}$ and $\mathrm{Al}$ have been leached upon their combined sulfate leach liquor. Under the optimum conditions, leaching efficiencies of about $100 \%$ for $\mathrm{U}, 88 \%$ for REEs, $68.57 \%$ for $\mathrm{Cu}, 66.52 \%$ for $\mathrm{Zn}$ and $37.51 \%$ for $\mathrm{Al}$ have been achieved.

The work was then shifted for the recovery of boron from the residue left behind.The latter was accomplished by roasting with sodium hydroxide to achieve $95 \%$ leaching efficiency. From the two adequately obtained leach liquors, marketable products have conveniently been prepared.

Copy Right, IJAR, 2017,. All rights reserved.

\section{Introduction:-}

Recovery of uranium and possible associated valuable elements is one of the most important concerns of the Nuclear Materials Authority of Egypt. Among the discovered mineralization, the Carboniferous rocks sequence at SW Sinai represents indeed a promising terrain for uranium and other valuable economic metals in association with Um Bogma Formation. The latter includes mainly $\mathrm{Cu}, \mathrm{V}, \mathrm{REE}$ besides the famous Fe/Mn deposits in different concentrations in several localities and rock facies of this formation; viz ,Allouga, Talatselim, Abu Thor, etc.

Mineralogically, Abu Thor $\mathrm{Cu}-\mathrm{U}$ mineralization is essentially composed of the copper carbonate minerals malachite $\left[\mathrm{Cu}_{2}(\mathrm{OH})_{2} \mathrm{CO}_{3}\right]$ and azurite $\left[\mathrm{Cu}_{3}(\mathrm{OH})_{2}\left(\mathrm{CO}_{3}\right)_{2}\right]$ and to a much less extent the chloride mineral atacamite $\mathrm{CuCl}_{2} .3 \mathrm{Cu}(\mathrm{OH})_{2} \mathrm{Amer}(\mathbf{1 9 9 7})^{(1)}$. On the other hand, according to this author uranium in Abu Thor mineralization is essentially present either in the form of its secondary minerals uranophane, beta uranophane which is found in nearby mineralizations, however, in a finely-divided form or else adsorbed on the gangue minerals e.g. clays and iron oxides. Mira and Aita, (2009) ${ }^{(2)}$ identified $\mathrm{Cu}$ and U-bearing minerals include mainly: atacamite $\left[\mathrm{Cu}_{2} \mathrm{Cl}(\mathrm{OH})_{3}\right], \mathrm{paratacamite}$ $(\mathrm{Cu}, \mathrm{Zn})_{2}(\mathrm{OH})_{3} \mathrm{Cl}$ or $\mathrm{Cu}_{1.5} \mathrm{Zn}_{0.5}(\mathrm{OH})_{3} \mathrm{Cl}$, malachite $\left[\mathrm{Cu}_{2}(\mathrm{OH})_{2} \mathrm{CO}_{3}\right]$, rosasite $\left.\left[(\mathrm{Cu}, \mathrm{Zn})_{2}(\mathrm{CO})_{3}\right)(\mathrm{OH})_{2}\right]$, monazite $\left[(\mathrm{Ce}, \mathrm{La}) \mathrm{PO}_{4}\right]$ and $\mathrm{K}$ - rich zippeite $\mathrm{K}_{4}\left(\mathrm{UO}_{2}\right)_{6}\left(\mathrm{SO}_{4}\right)_{3}(\mathrm{OH})_{10} \cdot 4\left(\mathrm{H}_{2} \mathrm{O}\right)$. 
The main target of the present work is to recover uranium and possible associated elements from the ferruginous gibbsite-bearing shale of Um Bogma Formation at Abu Thor locality. Actually, The gibbsite bearing shale occurs at different locations and besides its interesting $\mathrm{Al}$ content, it can be considered as a polymetallic ore as it is associated with varying amounts of $\mathrm{U}, \mathrm{Zn}, \mathrm{Cu}, \mathrm{Co}, \mathrm{Ni}, \mathrm{REE}, \mathrm{V}$, et...... In this regard, for the recovery of the different contained metal values several studies have previously been done using sulfuric acid leaching upon Abu Zeneima mineralized ore material. Accordingly, Amer (1993) $)^{(3)}$ and $(\mathbf{1 9 9 7})^{(1)}$ has applied the ion exchange and or solvent extraction techniques for the extraction of U using Amberlite IRA-400 anion exchange resin and or the organic solvent extractant almanine 336 and LIX-64N for Cu. Mahdy (1995) ${ }^{(4)}$ has presented a number of flowsheets for the recovery of $\mathrm{U}, \mathrm{Cu}$ and $\mathrm{Mn}$ using different methods such as precipitation, crystallization besides using the organic solvents as well as the anion exchange resin. Also, Abdel Fattah (2003) ${ }^{\mathbf{( 5 )}}$ has studied the leaching and extraction efficiency of $\mathrm{Al}, \mathrm{Cu}, \mathrm{Zn}$ and $\mathrm{U}$ from a gibbsite ore material of west central Sinai and proposed two flowsheets. In these flowsheets, the alkali one include both $\mathrm{U}$ and $\mathrm{Al}$ recovery by caustic soda containing some $\mathrm{Na}_{2} \mathrm{CO}_{3}$; then by passing $\mathrm{CO}_{2}$ into this liquor, $\mathrm{Al}$ was precipitated while $\mathrm{U}$ could be recovered from the filtrate by anion exchange resin. The $\mathrm{Cu}$ and $\mathrm{Zn}$ left behind in the ore were then leached by dilute $\mathrm{H}_{2} \mathrm{SO}_{4}$ acid followed by metallic $\mathrm{Cu}$ precipitation by $\mathrm{Zn}$ dust. The dissolved $\mathrm{Zn}$ was recovered by precipitation at $\mathrm{pH} 8.4$ after Fe(III) removal at pH 3.03.5. In the acid flowsheet; $\mathrm{Al}, \mathrm{Cu}, \mathrm{Zn}$ and $\mathrm{U}$ were leached by $\mathrm{H}_{2} \mathrm{SO}_{4}$. After $\mathrm{Cu}$ recovery by metallic $\mathrm{Zn}$ at $\mathrm{pH} 1, \mathrm{U}$ was recovered by anion exchange resin. The solution $\mathrm{pH}$ was then adjusted to $\mathrm{pH} 5.3$ to precipitate $\mathrm{Al}$ (III) and Fe (III) for later separation by selective caustic soda leach of Al. The filtrate from the $\mathrm{Al}-\mathrm{Fe}$ cake was treated for the recovery of dissolved $\mathrm{Zn}$ values by $\mathrm{pH}$ adjustment to 7.5. On other hand, El Hazek, et al., (2008) ${ }^{(6)}$ reported that the agitation acid leaching is preferred to leach most of the interested metal values namely; $\mathrm{Al}, \mathrm{Cu}, \mathrm{Zn}, \mathrm{Co}, \mathrm{Ni}, \mathrm{REE}$ of the gibbsite shales belonging to the Paleozoic sequence of sedimentary rocks occurring at Abu Zeneima area of SW Sinai, The optimum acid agitation leaching conditions involves working at $800 \mathrm{~g} / \mathrm{L} \mathrm{H}_{2} \mathrm{SO}_{4}$ acid in a S/L ratio of $1 / 2$ at $100{ }^{\circ} \mathrm{C}$ for $12 \mathrm{~h}$ and using an ore mesh sizeof -60 mesh. Under these conditions, it is possible to achieve the following leaching efficiencies: Al 100\%, Cu 100\%, Co 91\%, Zn $84 \%$, Ni 100\% and U 95\%.

It is interesting to mention herein that, Ibrahim and El-Sheikh(2011) ${ }^{(\mathbf{7})}$ have applied a proper bioleaching processing for a carbonate rich mineralized gibbsite ore material from Abu Zeneima area, SW Sinai. The metal values of this ore material included $0.34 \% \mathrm{Zn}, 0.49 \%$ REEs and $0.05 \% \mathrm{U}$ beside $26.43 \% \mathrm{Al}_{2} \mathrm{O}_{3}$.In the bioleaching process, the columnar technique was applied upon non-sterilized material including the use of 5\% Acidithio bacillus ferrooxidans bacteria and circulating the bioleach liquor for 30 cycles. Under these conditions, the obtained leaching efficiencies amounted to about $67.6,55,50$ and $22.4 \%$ for the REEs, uranium, zinc and aluminum respectively.

As previously mentioned, the main target of this study is to recover $\mathrm{U}$, and REEs and $\mathrm{B}$ together with $\mathrm{Cu}, \mathrm{Zn}$ and $\mathrm{Al}$ and Si from the study ferruginous gibbsite-bearing shale of Um Bogma Formation at Abu Thor locality.To realize this goal, a technological representative sample of Abu Thor mineralization was properly collected which was found to assay $0.04 \% \mathrm{U}, 0.2143 \%$ REEs, $1 \% \mathrm{Zn}, 2.3 \% \mathrm{Cu}$ and $38 \% \mathrm{Al}_{2} \mathrm{O}_{3}$. Acidic leaching was applied for $\mathrm{U}, \mathrm{REEs}, \mathrm{Cu}$, $\mathrm{Zn}$ and $\mathrm{Al}$ recovery followed by alkali roasting for recovering $\mathrm{B}$ from the spent residue by using sodium hydroxide. Different parameters affecting the leaching processes such as acid/or alkali concentration, leaching time, solid / liquid ratio, and temperature of the system were investigated.

\section{Experimental:-}

\section{Materials and methods:-}

\section{Characterisation of the working sample:-}

Proper quartering of the technological sample was performed after its grinding to less than 200 mesh size to obtain a representative sample which was subjected to complete chemical analyses of both major and trace elements content. For the former, the conventional wet chemical technique was applied (Shapiro and Brannock, 1962) ${ }^{(\mathbf{8})} \mathrm{where} \mathrm{SiO}_{2}$, $\mathrm{Al}_{2} \mathrm{O}_{3}, \mathrm{TiO}_{2}$ and $\mathrm{P}_{2} \mathrm{O}_{5}$ were determined using their relevant spectrophotometric methods while $\mathrm{Na}_{2} \mathrm{O}$ and $\mathrm{K}_{2} \mathrm{O}$ were assayed by the flame photometric technique. Total $\mathrm{Fe}$ as $\mathrm{Fe}_{2} \mathrm{O}_{3}, \mathrm{MgO}$ and $\mathrm{CaO}$ were determined by titration methods against dichromate and EDTA solutions respectively. The loss on ignition (L.O.I) was gravimetrically determined at $550{ }^{\circ} \mathrm{C}$ for $\mathrm{H}_{2} \mathrm{O}, \mathrm{H}-\mathrm{O}^{-}$and organic matter as well as at $1000^{\circ} \mathrm{C}$ for $\mathrm{CO}_{2}$. The estimated error for these major constituents is not more than $\pm 1 \%$.

The trace elements $\mathrm{V}, \mathrm{Nb}, \mathrm{Ni}, \mathrm{Cu}, \mathrm{Zn}, \mathrm{Y}, \mathrm{Zr}$, and $\mathrm{Pb}$ were also analyzed by means of the $\mathrm{X}$-ray fluorescence technique (XRF) using Philips Unique II unit fitted with an automatic sample changer PW 1510 (30 position), connected to a computer system using X-40 program for spectrometry. The detection limit of the measured elements by means of XRF technique was estimated to be $5 \mathrm{ppm}$. 


\title{
Leaching procedures:-
}

In this process, the ground sample (-200 mesh size) was well mixed by quartering to attain homogeneity. However, several sample portions were subjected to the leaching experiments.

In the present work, two leaching methods were subsequently performed; the first includes acidic agitation leaching by using $\mathrm{H}_{2} \mathrm{SO}_{4}$ acid upon the raw ore material to dissolve both of $\mathrm{U}$, REEs and some of the associated elements such as $\mathrm{Zn}, \mathrm{Cu}$ and $\mathrm{Al}$, leaving behind $\mathrm{B}$ and $\mathrm{Si}$ in the residue. While the other includes the spent residue which was roasted with $\mathrm{NaOH}$ to dissolve the unleached $\mathrm{B}$ and $\mathrm{Si}$.

\section{$\mathrm{H}_{2} \mathrm{SO}_{4}$ acid atmospheric agitation leaching:-}

Each leaching experiment has been performed by agitating a weighed amount of the ground sample (10g) with $\mathrm{H}_{2} \mathrm{SO}_{4}$ acid of different concentrations, different solid/liquid ratios(S/L) for different periods of time at different temperatures. In these experiments, a hot plate with magnetic stirrer was used and precautions were taken to avoid evaporation. The obtained slurry was then filtered and the residue left behind was thoroughly washed with distilled water. Both of filtrate and washings were made up to volume before analysis of the leached metal values.

\begin{abstract}
Alkali roasting of the spent residue :-
To recover boron from the spend residue, obtained after applying acidic leaching, alkali roasting process was conducted by mixing solid $\mathrm{NaOH}$ with the spent residue at slightly high temperature for different periods of times. After that the cooled roasted matrix was then undergoes water leaching to dissolve its boron contents. It is worthy to mention herein that, all the roasting experiments were conducted by using constant weight $(5 \mathrm{~g})$ of the working residual sample.
\end{abstract}

\section{Recovery procedures:-}

Recovery of $U$ and REEs:-

According to the chemical characteristics of the studied metal values, it can be mentioned that $\mathrm{Al}, \mathrm{Cu}$ and $\mathrm{Zn}$ beside most of undesired metal impurities exist in sulfate liquors in their cationic forms except the uranium exist in both cationic and anionic forms. Therefore, anion exchange resin would be selective for uranium recovery from the obtained sulfate leach liquor. In order to improve recovery of uranium, without interference of other elements, especially $\mathrm{Fe}$, the latter must be firstly removed at $\mathrm{pH}$ of 3 . In the latter solution, the competing anions include mainly $\mathrm{SO}_{4}{ }^{2-}$ and $\mathrm{HSO}^{4-}$ and therefore uranium would be better adsorbed at $\mathrm{pH}$ value exceeding 1.8 while below this value, $\mathrm{HSO}_{4}{ }^{-}$would be strongly adsorbed. (Merritt, 1971 $^{(\mathbf{9})}$; Preuss and Kurrin, 1965) ${ }^{(\mathbf{1 0})}$.

In the present work the $\mathrm{pH}$ of the prepared pregnant solution was re-adjusted to $\mathrm{pH} 1.8$ for $\mathrm{U}$ adsorption upon the anion exchanger resin Amberlite IRA-400 while the effluent was then used to precipitate $\mathrm{Cu}$ and $\mathrm{Al}$ as their hydroxides at $\mathrm{pH}$ of 5.5.The separation between copper hydroxide and aluminum hydroxide takes place by adding excess of $35 \%$ ammonia solution to dissolved the copper selectivity.

$\mathrm{U}, \mathrm{Cu}$ and $\mathrm{Al}$ free solution was then directed to precipitate zinc. The latter was directly precipitated as its sulfide from the sulfate leach liquor after adjusting its $\mathrm{pH}$ to 2 using a $2 \% \mathrm{Na}_{2} \mathrm{~S}$ solution.

The $\mathrm{Zn}$ - free leach liquor was then subjected to the precipitation of the total REE as their oxalates by the addition of $30 \%$ oxalic acid at $\mathrm{pH} 1$.

\section{Recovery of B:-}

In the present work, trials to recover boron from the pre-processed ore material under consideration have been performed. In this respect, alkali roasting process was first accomplished upon $500 \mathrm{~g}$ of the ore residue by using pellets of $\mathrm{NaOH}$ under the obtained optimum roasting conditions. The roasted matrix was then left to cool and leached with distilled water for $0.5 \mathrm{~h}$ at room temperature to bring out the dissolved boron metal value. The recovery of boron has been performed viaAmberlite IRA-743 anion exchange resin. Fractions of $100 \mathrm{~mL}$ bed volumes were collected and its boron content was estimated to determine the relative loading efficiency of boron upon the applied flow rate of $1.5 \mathrm{~mL} / \mathrm{min}$. The saturated loaded resin was subjected to the elution process to regenerate the loaded boron. Hot water was used to attain acceptable elution efficiency of B. For this purpose, suitable volume of $100 \mathrm{~mL}$ hot distilled $\mathrm{H}_{2} \mathrm{O}$ was used at working flow rate of $1 \mathrm{~mL} / \mathrm{min}$ to remove almost loaded $\mathrm{B}$. The eluate rich boron was subjected to evaporation to prepare pure $\mathrm{H}_{3} \mathrm{BO}_{3}$ acid. 


\section{Analytical procedures:-}

To follow the periodical analyses in the obtained leach liquors from the different stream solutions, oxidimetric titration method against ammonium metavanadate was used for uranium analysis after its reduction (Mathew et al., 2009) ${ }^{(\mathbf{1 1})}$. While for copper and zinc, an atomic absorption spectrometer (AAS) Unicam 969, England was used. Total rare earth elements were spectrophotometer determined by the colored method using Arsenazo-III, as an indicator (Merczenko, 1986) ${ }^{(12)}$.

On the other hand, B analysis was performed by using prism ICP-OES, Teledyne technologies (Inductively Coupled Plasma Optical Emission Spectrometer). Also, the final obtained products of all study metal values have qualitatively been analyzed using the ESEM-EDX analysis.

\section{Results AndDiscussion:-}

Chemical characteristics of the working ferruginous gibbsite-bearing shale ore material:-

The chemical composition of the working Abu Thor ore sample is given in table (1). From this table, it is clear that the high level of the loss on ignition (attaining about 20\%) reflect its high content of organic matter on the expense of carbonates as shown from its low contents of $\mathrm{CaO}$ and $\mathrm{MgO} \approx 0.57 \%$. Also, silica, alumina and iron oxide contents are also of high content, $21.75,38.09$ and $11.39 \%$ respectively together with $1.6 \%$ of $\mathrm{P}_{2} \mathrm{O}_{5}$ and $\mathrm{TiO}_{2}$.

On other hand, X-ray fluorescence (XRF) analyses of some trace elements (Table 2) shows that U attains $404 \mathrm{ppm}$ besides interesting values of Zn, Ni, Y, B and $\sum$ REEs ; namely 10000, 1784, 69 , 1000 and $2143 \mathrm{ppm}$ respectively. Some of the corresponding minerals are included in the host rocks which essentially represented by hematite besides variable amounts of rutile, jarosite, goethite, crednerite $\left(\mathrm{CuMnO}_{2}\right)$, kaolinite, alunite, gibbsite, hausmannite, phosphosiderite and lawrencite $\left(\mathrm{FeNiCl}_{2}\right)(\mathbf{A i t a}, \mathbf{1 9 9 6})^{(\mathbf{1 3 )}}$.

Table (1):- Chemical composition of the working gibbsite bearing shale ore sample

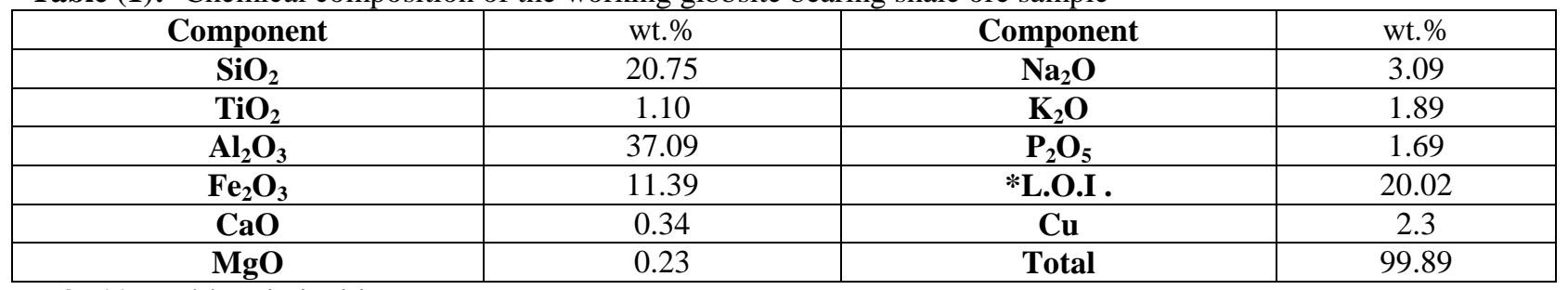

L.O.I**Total loss in ignition

Table (2):- Trace elements Content in the working gibbsite bearing shale ore sample.

\begin{tabular}{|c|c|c|c|}
\hline Trace element & ppm & Trace element & Ppm \\
\hline $\mathbf{N i}$ & 1784 & $\mathbf{V}$ & 203 \\
\hline $\mathbf{N b}$ & 29 & $\mathbf{U}^{*}$ & 404 \\
\hline $\mathbf{Z r}$ & 598 & $\sum \mathbf{R E E s} \boldsymbol{*}^{*}$ & 2143 \\
\hline $\mathbf{P b}$ & 3855 & $\mathbf{Z n}^{*}$ & 10000 \\
\hline $\mathbf{Y}$ & 69 & $\mathbf{B}^{*}$ & 1000 \\
\hline
\end{tabular}

*= Wet Chemical determination

\section{Results of $\mathrm{H}_{2} \mathrm{SO}_{4}$ acid atmospheric agitation leaching:-}

\section{Effect of acid concentration:-}

The sulfuric acid concentration used for studying its effect upon the agitation leaching efficiency of U, REEs, Cu, Al and $\mathrm{Zn}$ values has been varied between 80 and $240 \mathrm{~g} / \mathrm{L}$. The other leaching conditions were fixed for only one hour at $70{ }^{\circ} \mathrm{C}$ within the $\mathrm{S} / \mathrm{L}$ ratio of $1 / 2$ and using an ore ground to -200 mesh size. The obtained results Table.(3) indicate that, increasing the acid concentration has a direct influence upon the leaching efficiencies of the studied metal values. Thus, as the acid concentration increased from 80 to $200 \mathrm{~g} /$, the leaching efficiency of $\mathrm{U}$ increased from $20 \%$ to $40 \%$ while the leaching efficiencies of REEs increased from 25.23 to $37.51 \%$ and $\mathrm{Cu}, \mathrm{Al}$ and $\mathrm{Zn}$ increased from 20.29 to $30.44 \%, 22.40$ to $29.91 \%$ and 50.00 to $62.29 \%$ respectively. On the other hand, further increase in the acid concentration (i.e. $240 \mathrm{~g} / \mathrm{L}$ ) slightly improved the leaching efficiencies of $\mathrm{U}, \mathrm{Cu}, \mathrm{Zn}$, and $\mathrm{Al}$ to $45,35,81$ and $32.41 \%$ respectively. It is important to mention herein that further increase in the acid concentration (i.e.240 $\mathrm{g} /$ ) has an adverse effect on the leaching efficiency of REEs. This may be due to partial precipitation of 
LREEs as double sulfates. It can thus be mentioned that the $200 \mathrm{~g} / \mathrm{L}$ sulfuric acid concentration that is optimum leaching concentration for different metal values.Also, it is evident that $\mathrm{B}$ dissolution has not be affected to any extent by increasing the acid concentration.

Table (3):- Effect of acid concentration leaching efficiency upon the study metal values of gibbsite-bearing shale ore material.

\begin{tabular}{|c|c|c|c|c|c|c|}
\hline \multirow[b]{2}{*}{ Acid Conc., g/L } & \multicolumn{6}{|c|}{ Leaching efficiency, \% } \\
\hline & $\mathbf{U}$ & $\sum$ REEs & $\mathbf{C u}$ & Al & Zn & $\mathbf{B}$ \\
\hline 80 & 20 & 25.23 & 20.92 & 22.40 & 50.00 & $* \mathrm{ND}$ \\
\hline 120 & 25 & 28.56 & 19.57 & 22.50 & 53.65 & $* \mathrm{ND}$ \\
\hline 160 & 30 & 32.95 & 15.66 & 28.99 & 60.66 & $* \mathrm{ND}$ \\
\hline 200 & 40 & 37.51 & 30.44 & 29.91 & 62.29 & $* \mathrm{ND}$ \\
\hline 240 & 45 & 32.40 & 35.00 & 32.41 & 81.80 & $* \mathrm{ND}$ \\
\hline
\end{tabular}

$* \mathrm{ND}=$ Non detected

\section{Effect of Leaching Time:-}

To study the effect of agitation time upon the leaching efficiencies of the metal values of Abu Thor gibbsite ore material, a series of leaching experiments were studied at different periods of time ranging from one hour to $4 \mathrm{~h}$ under fixed conditions of $200 \mathrm{~g} / \mathrm{L} \mathrm{H}_{2} \mathrm{SO}_{4}$ acid at $70^{\circ} \mathrm{C}$ and using $1 / 2 \mathrm{~S} / \mathrm{L}$ ratio. The leaching efficiencies of the interested metal values are given in Table (4). From the obtained results it is clear that the leaching efficiencies of $U$ and associated elements increased by increasing the agitation time from an hour to $4 \mathrm{~h}$ from 40 to $75 \%$ for $\mathrm{U}$, from 30.44 to $54.51 \%$ for $\mathrm{Cu}$, from 29.91 to 39.34 for $\mathrm{Al}$ and from 62.29 to 76.3 for $\mathrm{Zn}$.

It is worthy to mention herein that REEs dissolution efficiency increased from 37.5 at $1 \mathrm{~h}$ to $84.1 \%$ at $3 \mathrm{~h}$. Increase leaching time to 4 or $5 \mathrm{~h}$ doesn't increase the leaching efficiency of REEs due to its precipitation as double sulfates. Finally, it can be stated that extending the leaching time to $4 \mathrm{~h}$ is quite beneficial where satisfied leaching amount of $\mathrm{U}$ and most of the other associated element were achieve in this context, it is noted that the B content of the study ore material does not effected even when the leaching time was increased.

Table (4):- Effect of leaching time leaching efficiency upon the study metal values of gibbsite-bearing shale ore material

\begin{tabular}{|c|c|c|c|c|c|c|}
\hline \multirow{2}{*}{ Time,h } & \multicolumn{5}{|c|}{ Leaching efficiency, \% } \\
\cline { 2 - 7 } & $\mathbf{U}$ & $\sum$ REEs & $\mathbf{C u}$ & $\mathbf{A l}$ & Zn & B \\
\hline $\mathbf{1}$ & 40 & 37.51 & 30.44 & 29.91 & 62.29 & $*$ ND \\
\hline $\mathbf{2}$ & 65 & 65.42 & 40.11 & 38.88 & 70.80 & $*$ ND \\
\hline $\mathbf{3}$ & 70 & 84.08 & 48.83 & 39.33 & 75.00 & $*$ ND \\
\hline $\mathbf{4}$ & 75 & 80.80 & 54.51 & 39.34 & 76.23 & $*$ ND \\
\hline $\mathbf{5}$ & 75 & 80.80 & 54.51 & 39.34 & 76.23 & $*$ ND \\
\hline
\end{tabular}

$* \mathrm{ND}=$ Non detected

\section{Effect of leaching temperature:-}

The effect of leaching temperature upon the dissolution efficiencies of the studied metal values was studied in the range from room temperature $\left(25^{\circ} \mathrm{C}\right)$ up to $95^{\circ} \mathrm{C}$. The other leaching conditions were fixed at $200 \mathrm{gL} \mathrm{H}_{2} \mathrm{SO}_{4}$ acid, $4 \mathrm{~h}$ agitation time and $\mathrm{S} / \mathrm{L}$ ratio of $1 / 2$. The obtained data which are shown in Table. (5) indicated the importance of leaching temperature upon the study metal value leaching efficiencies from this ore material. Also, this effect is actually more pronounced in case of $\mathrm{U}$, REEs, $\mathrm{Cu}$ and $\mathrm{Zn}$ which gave better results than those of $\mathrm{Al}$ in spite of using the same experimental conditions. This may be due to the hydrolysis effect that might have led to $\mathrm{Al}$ reprecipitation. Working at room temperature under the mentioned conditions did not leach more than $50 \%$ of $\mathrm{U}$, $55.67 \%$ REEs, $37.58 \%$ of $\mathrm{Cu}$ and $26.83 \%$ of $\mathrm{Al}$ while that of zinc amounted to $60.15 \%$. Increasing the leaching temperature to $65^{\circ} \mathrm{C}$ has increased the leaching efficiency of $\mathrm{U}, \mathrm{REEs}, \mathrm{Cu}, \mathrm{Al}$ and $\mathrm{Zn}$ to 70, 75.71, 65.45, 38.34 and $75.0 \%$ respectively. Further increase to $95^{\circ} \mathrm{C}$ increased the $\mathrm{U}, \mathrm{REEs}, \mathrm{Cu}, \mathrm{Al}$ and $\mathrm{Zn}$ to leaching efficiency to 85 , $80.87,65.54,39.35$ and $85.00 \%$. It can thus be mentioned that the optimum leaching temperature using $200 \mathrm{~g} / \mathrm{L}$ sulfuric acid under the above mentioned condition would be $95^{\circ} \mathrm{C}$.Also, B dissolution was not affected by any increase in leaching temperature 
Table (5):-Effect of temperature leaching efficiency upon the study metal values of gibbsite-bearing shale ore material

\begin{tabular}{|c|c|c|c|c|c|c|}
\hline \multirow{2}{*}{ Temperature, ${ }^{\circ} \mathrm{C}$} & \multicolumn{7}{|c|}{ Leaching efficiency,\% } \\
\cline { 2 - 7 } & $\mathrm{U}$ & $\sum$ REEs & $\mathrm{Cu}$ & $\mathrm{Al}$ & $\mathrm{Zn}$ & $\mathrm{B}$ \\
\hline 25 & 50 & 55.67 & 37.58 & 26.83 & 60.15 & $*$ ND \\
\hline 45 & 60 & 60.36 & 50.28 & 30.26 & 70.74 & $*$ ND \\
\hline 65 & 70 & 75.71 & 65.45 & 38.34 & 75.00 & $*$ ND \\
\hline 70 & 75 & 80.80 & 54.51 & 39.34 & 76.23 & $*$ ND \\
\hline 75 & 78 & 80.82 & 60.37 & 39.23 & 80.11 & $*$ ND \\
\hline 85 & 80 & 80.86 & 61.52 & 39.35 & 82.44 & $*$ ND \\
\hline $\mathbf{9 5}$ & 85 & 80.87 & 65.54 & 39.35 & 85.00 & *ND \\
\hline
\end{tabular}

$* \mathrm{ND}=$ Non detected

Effect of S/L ratio:-

As the solid/liquid ratio in the leaching slurry would control its viscosity and hence efficient mixing; its effect was therefore studied in the range of $1 / 2$ to $1 / 5$. The other leaching conditions were fixed at $200 \mathrm{~g} \mathrm{~L} \mathrm{H}_{2} \mathrm{SO}_{4}$ and $4 \mathrm{~h}$ agitation time at $95^{\circ} \mathrm{C}$. From the obtained data shown in Table (6), the dissolution efficiencies of all metal values increased by decreasing the solid liquid ratio from $1 / 2$ to $/ / 4$. In other words, the metal values leaching efficiency are increased with increasing the amount of acid input to the ore weight. It was found that after the S/L ratio of $1 / 4$ a perceptible decrease in the leaching efficiencies of $\mathrm{U}$ to $90 \%$ and REEs to $80.77 \%$ took place. With respect to the other metal values a significant increase in the leach efficiency was achieved. Accordingly, a solid/liquid ratio of $1 / 4$ would be considered as optimum for the high dissolution efficiency of $U$ and REE.

Table(6):-Effect of the S/L ratio leaching efficiency upon the study metal values of gibbsite-bearing shale ore material

\begin{tabular}{|l|c|c|c|c|c|c|}
\hline \multirow{2}{*}{ Solid/liquid, Ratio } & \multicolumn{7}{|c|}{ Leachi g efficiency,\% } \\
\cline { 2 - 7 } & $\mathbf{U}$ & $\sum$ REEs & Cu & Al & Zn & B \\
\hline $\mathbf{1 / 2}$ & 85 & 80.87 & 65.54 & 39.35 & 85.00 & $*$ ND \\
\hline $\mathbf{1 / 3}$ & 90 & 84.53 & 67.94 & 38.35 & 70.55 & $*$ ND \\
\hline $\mathbf{1 / 4}$ & 99 & 88.54 & 68.57 & 37.51 & 66.52 & $*$ ND \\
\hline $\mathbf{1 / 5}$ & 90.13 & 80.77 & 75.99 & 47.91 & 90.00 & $*$ ND \\
\hline
\end{tabular}

*ND= Non detected

From the forgoing study it can be concluded that the optimum leaching conditions for almost complete leaching of $\mathrm{U}$ and $88.54 \%$ REEs and a satisfy amount of the other associated elements would be summarized as follows:

Grain size $-200 \mathrm{mesh}$

Acid concentration $\quad: \quad 200 \mathrm{~g} / \mathrm{L}$

Leaching time

Leaching temperature $\quad: \quad 95^{\circ} \mathrm{C}$.

Solid/liquid ratio $\quad: \quad 1 / 4$

Results of metal values recovery:-

For recovering of $\mathrm{U}$, REEs and the associated metal values, a sulfate leach liquor was probably prepared by applying the above mentioned optimum leaching conditions upon $1 \mathrm{~kg}$ of the provided working ore material. This resulted in $0.1,0.45,1.66,3.9$ and $35.71 \mathrm{~g} / \mathrm{L}$ within leaching efficiencies for $\mathrm{U}$, REEs, $\mathrm{Zn}, \mathrm{Cu}$ and $\mathrm{Al}$ respectively.

\section{Uranium recovery:-}

Loading of U upon Amberlite IRA400 resin:-

A resin sample of Amberlite IRA 400 equivalent to $4.35 \mathrm{ml}$ wet settled resin (w s r) was packed over a glass wool plug in a pyrex glass column. The prepared $4000 \mathrm{~mL}$ sulfate leach liquor was then subjected to loading process by passing through the prepared resin bed at the flow rate of about $1.4 \mathrm{~mL} / \mathrm{min}$. The effluent was collected every 200 $\mathrm{mL}$ that and analyzed for its uranium content .The obtained results which are shown in Fig (1) reflects the loading efficiency of $75 \%$ from the theoretical capacity of the study Amberlite IRA 400.

\section{Uranium Elution:-}

Before uranium elution, the resin column was first washed with distilled water displace of the pregnant solution. This 
was followed by passing the eluant solution composed of $1 \mathrm{~N} \mathrm{NaCl}$ acidified with $0.25 \mathrm{M}$ sulfuric acid using a flow rate of $1.4 \mathrm{~mL} / \mathrm{min}$. and collecting the obtained eluate every $10 \mathrm{~mL}$ for uranium analyses. The obtained elution efficiency for U was found to be $96.4 \%$.Fig (2).

\section{Uranium Precipitation:-}

Uranium from the collected eluate was precipitated at a pH of about 6.5 using $30 \% \mathrm{NH} 4 \mathrm{OH}$ solution in the form of ammonium diuranate as the following equation:

$$
2 \mathrm{UO}_{2}{ }^{++}+6 \mathrm{NH}_{4} \mathrm{OH} \rightarrow\left(\mathrm{NH}_{4}\right)_{2} \mathrm{U}_{2} \mathrm{O}_{7}+4 \mathrm{NH}_{4}^{+}+3 \mathrm{H}_{2} \mathrm{O} \text {. }
$$

After filtration and washing, the produced crude yellow cake (Y.C.) was then dried at $110{ }^{\circ} \mathrm{C}$ and its uranium content was chemically determined assaying about $75 \% \mathrm{U}$. EDAX analysis of the latter indicate $98 \%$ purity as shown in Fig. (3).

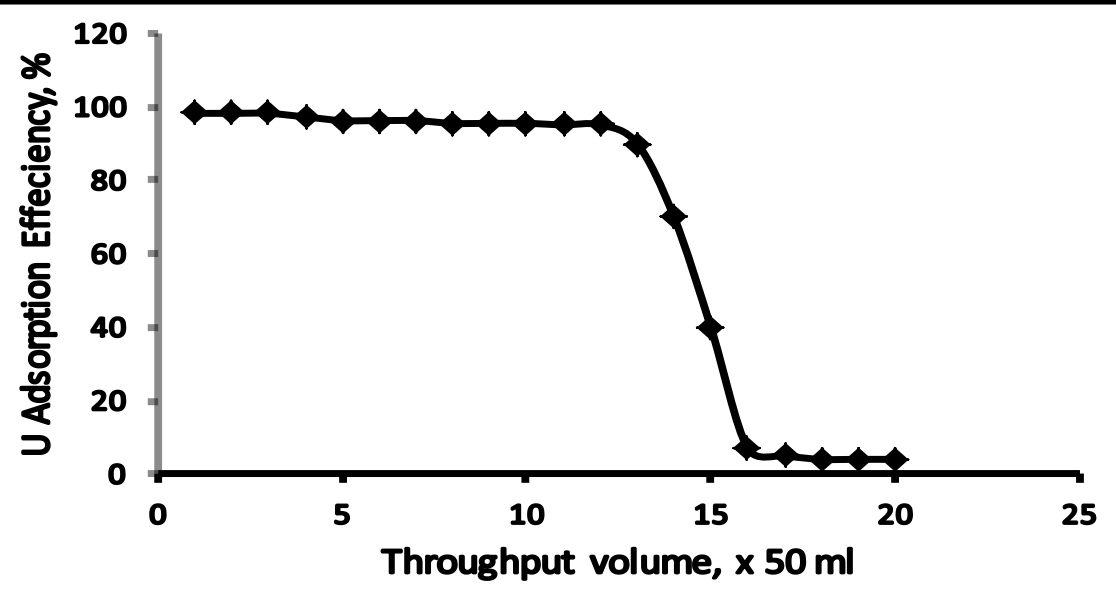

Fig. (1):- Adsorption curve of uranium from sulfate leach liquor.

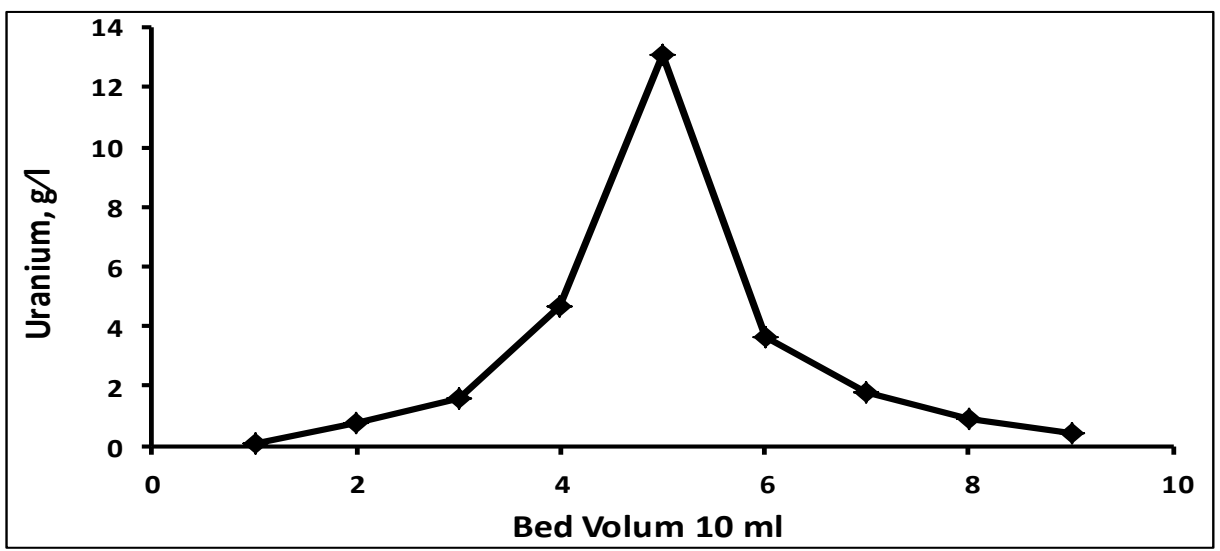

Fig.( 2):- U elution curve of saturated Amberlite IRA 400resin bed

\section{Selective Recovery of Total REEs:-}

As it is known either $\mathrm{Cu}$ or $\mathrm{Zn}$ greatly interfered during precipitation of the REE by using oxalic acid where it also forms an insoluble oxalate with those of the REEs. Therefore, $\mathrm{Cu}$, $\mathrm{Al}$ and $\mathrm{Zn}$ should be first removed from the sulfate leach liquor before the recovery of the REEs as their oxalates.

\section{Recovery of $\mathrm{Al}$ and Cu:-}

From the uranium effluent liquor, Cuand $\mathrm{Al}$ hydroxide crystals have been obtained by adjusting its $\mathrm{pH}$ to 5.5 using ammonia solution. The separation between copper hydroxide and aluminum hydroxide takes place by adding excess of $35 \%$ ammonia solution to dissolve the copper content selectivity according to the following equation: 


$$
\begin{array}{r}
\mathrm{Al}(\mathrm{OH})_{3} \downarrow+\mathrm{NH}_{4} \mathrm{OH} \rightarrow \mathrm{NH}_{4} \mathrm{AlO}_{2}+2 \mathrm{H}_{2} \mathrm{O} \ldots \ldots \ldots \ldots \ldots \ldots \ldots \ldots \ldots \ldots \ldots \ldots \ldots \\
2 \mathrm{NH}_{4} \mathrm{AlO}_{2}+\mathrm{H}_{2} \mathrm{SO}_{4}+2 \mathrm{H}_{2} \mathrm{O} \rightarrow 2 \mathrm{Al}(\mathrm{OH})_{3} \downarrow+\left(\mathrm{NH}_{4}\right)_{2} \mathrm{SO}_{4} \ldots \ldots \ldots \ldots \ldots \ldots \ldots \ldots \\
\mathrm{Cu}_{2}(\mathrm{OH})_{2} \mathrm{SO}_{4}+\left(\mathrm{NH}_{4}\right) 2 \mathrm{CO}_{3}+6 \mathrm{NH}_{4} \mathrm{OH} \rightarrow 2 \mathrm{Cu}\left(\mathrm{NH}_{3}\right) 4 \mathrm{CO}_{3}+8 \mathrm{H}_{2} \mathrm{SO}_{4}
\end{array}
$$

The obtained crystals of either $\mathrm{Cu}$ or $\mathrm{Al}$ have been calcined and the obtained oxides were then subjected to ESEM EDAX analysis to confirm the degree of its purity which was found to attain up to about $100 \%$ of both $\mathrm{Cu}$ and $\mathrm{Al}$ as shown inFig. $(4,5)$.

\section{Selective recovery of $\mathrm{Zn}:-$}

After removing of $\mathrm{U}, \mathrm{Cu}$ and $\mathrm{Al}$ from the prepared sulfate leach liquor, $\mathrm{Zn}$ was almost completely precipitated at $\mathrm{pH}$ 2 by using drop wise addition of $2 \% \mathrm{Na}_{2} \mathrm{~S}$ solution at room temperature; viz,

$$
\mathrm{ZnSO}_{4}+\mathrm{Na}_{2} \mathrm{~S} \rightarrow \mathrm{ZnS} \downarrow+\mathrm{Na}_{2} \mathrm{SO}_{4}
$$

After filtration, the gray $\mathrm{ZnS}$ precipitate was properly washed several times with distilled water to get rid of any included impurities. The obtained $\mathrm{ZnS}$ was identified by means of EDAX analysis with 90\% purity (Fig. 6).

Finally, the U, $\mathrm{Cu}, \mathrm{Al}$ and $\mathrm{Zn}$-free leach liquor was then subjected to the selective recovery of the total REEs through selective precipitation of their oxalates. This is due to the fact that, the REEs form stable insoluble oxalates and thus can be used for their separation (Habashi, 1993) ${ }^{(\mathbf{1 4})}$. Therefore, a $30 \%$ oxalic acid solution was used for this purpose after raising the $\mathrm{pH}$ value of the working effluent to 2.5. Almost complete precipitation of REEs was attained at $\mathrm{pH} 1$. These conditions represent the optimum conditions for the REEs precipitation. The obtained white REE-oxalate product was filtered and properly washed with distilled water to get ride of any impurities. After drying it was ignited at $850^{\circ} \mathrm{C}$ for $2 \mathrm{~h}$ to have the corresponding REE-oxides. The latter was subjected to EDAX semiquantitative analysis to identify its individual REEs distribution as shown in (Fig.7)

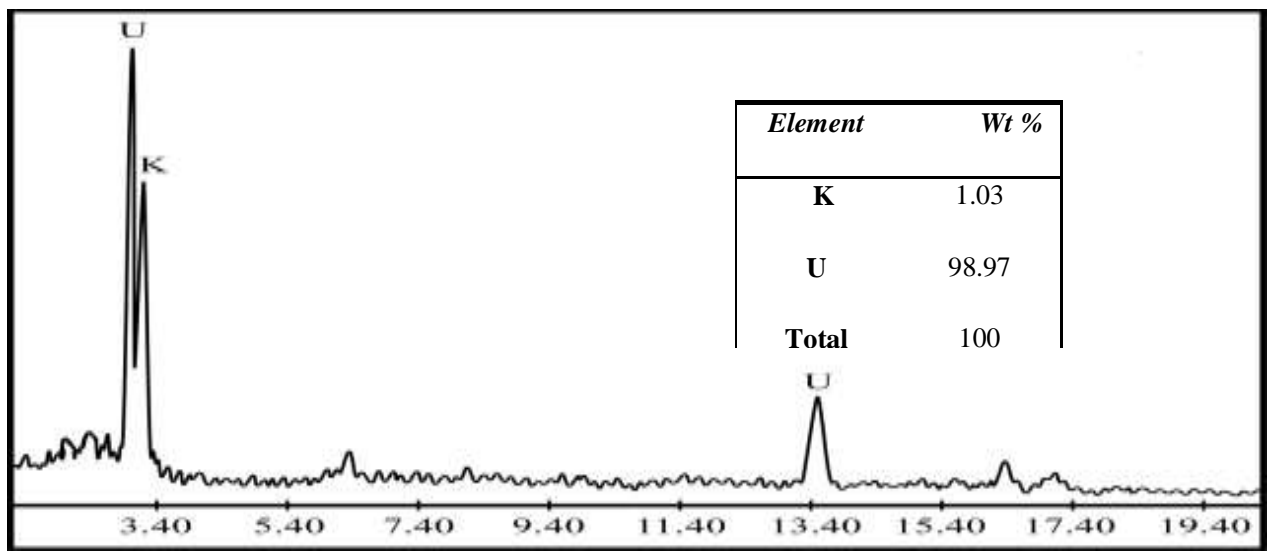

Fig. (3):- EDX analysis of the obtained crude yellow cake product.

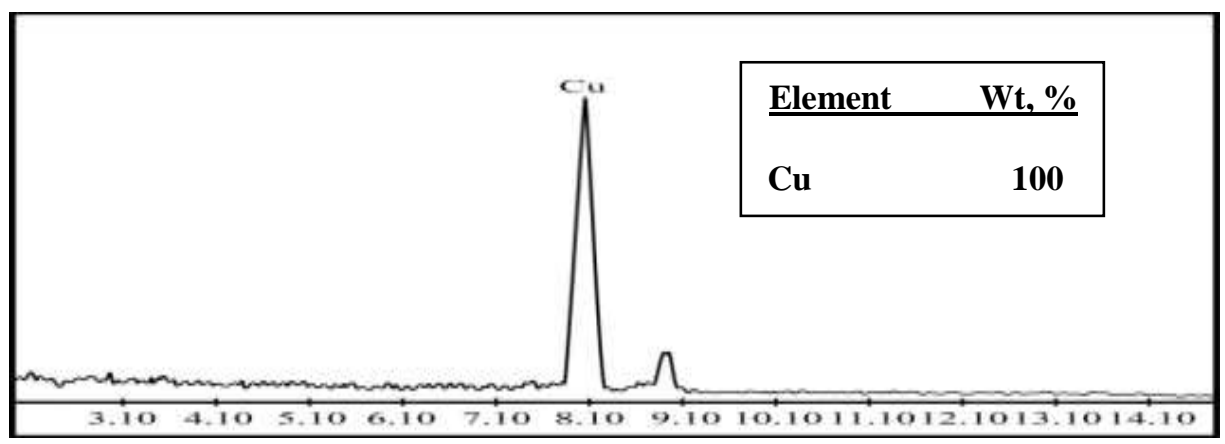

Fig. (4):- EDX analysis of the obtained pure copper 


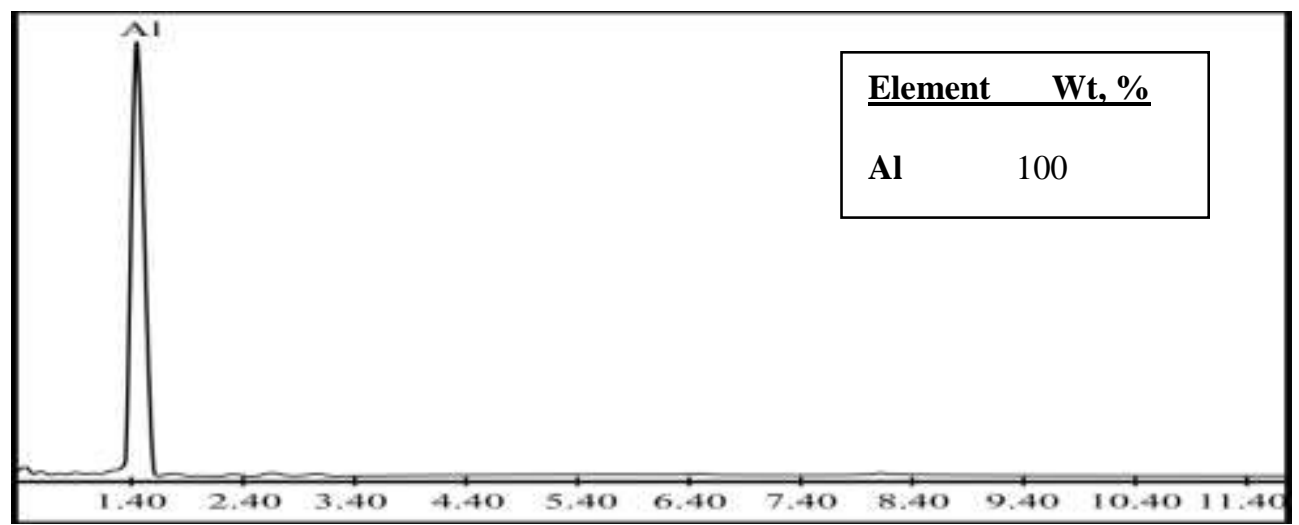

Fig. (5):- $\mathrm{EDX}$ analysis of obtained $\mathrm{Al}(\mathrm{OH})_{3}$.

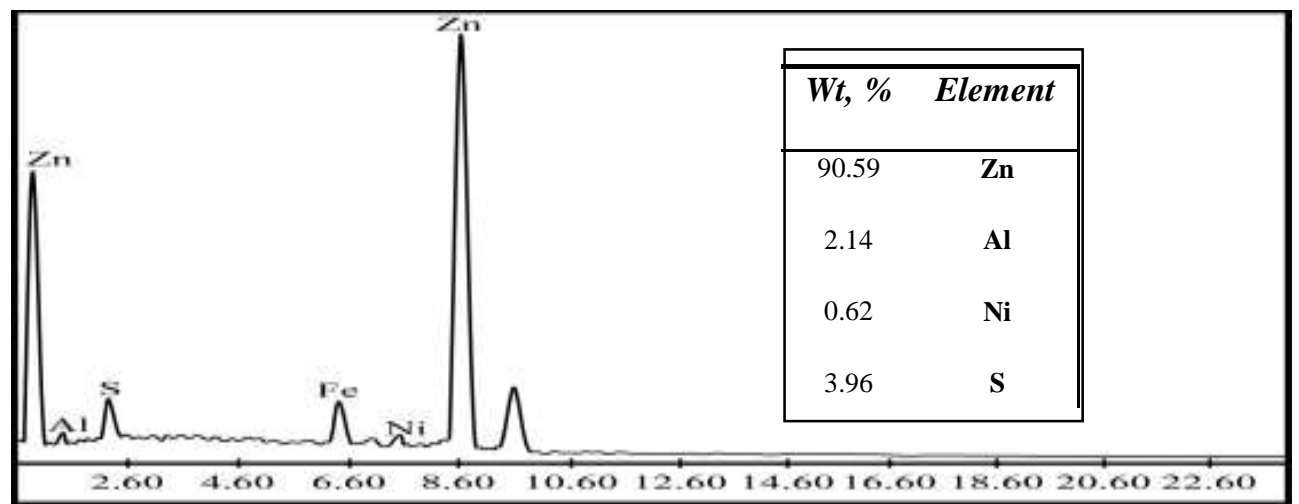

Fig. (6):- EDX analysis of the obtained zinc sulfide.

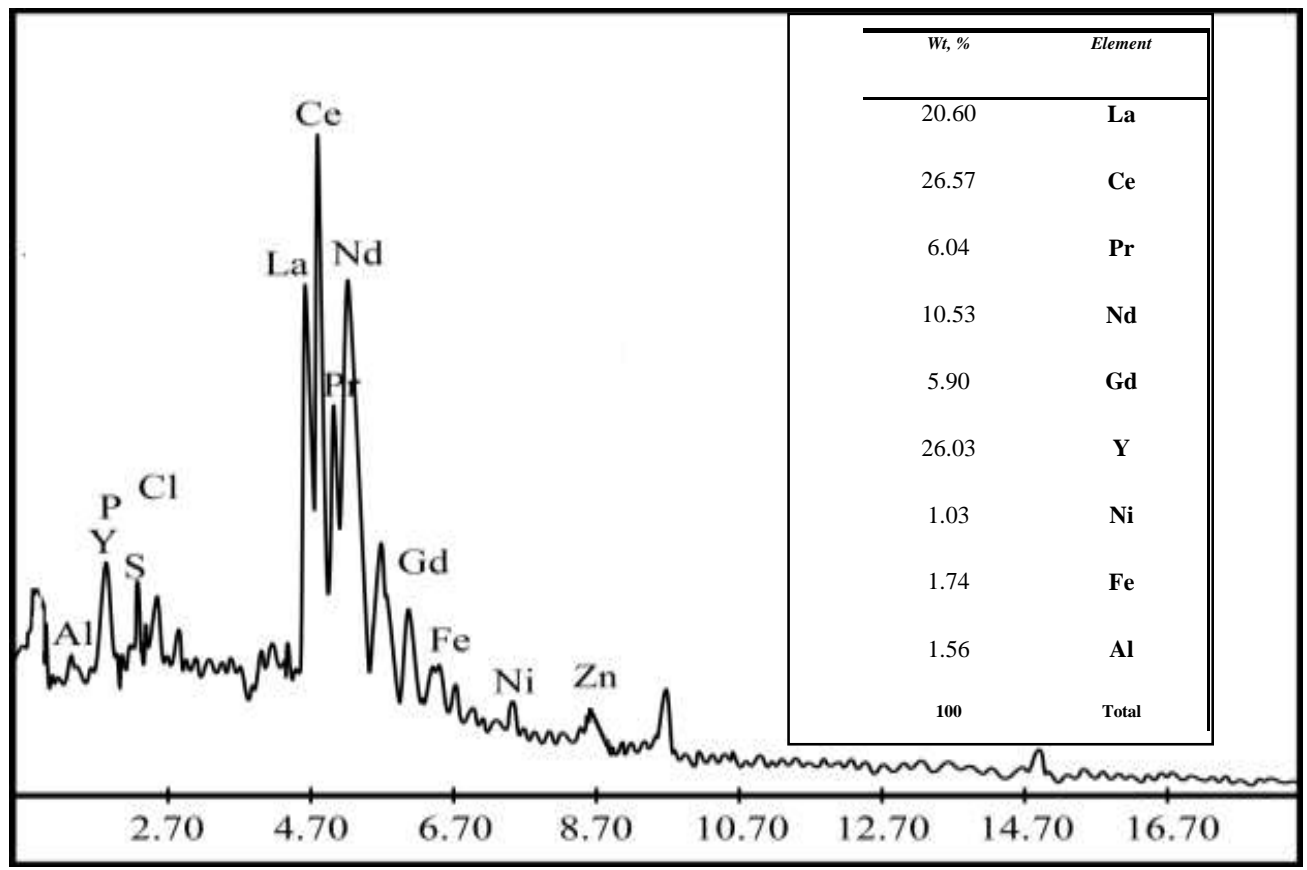

Fig. (7):- EDX analysis of obtained REE oxalate

\section{Results of alkali roasting of the spent ore residue:-}

As mentioned above, $\mathrm{U}$ and REEs, together with some of the associated metal values namely; $\mathrm{Cu}, \mathrm{Zn}$ and $\mathrm{Al}$ have successfully been recovered from the study raw ore material, the spent residue will represent the feed material of 
boron recovery. However, for this purpose alkali roasting process using $\mathrm{NaOH}$ was applied.

The main applicable alkali roasting conditions for recovering of B content include; effect of ore / $\mathrm{NaOH}$ weight ratios, roasting time and roasting temperature. Each experiment was performed on $5 \mathrm{~g}$ from the study ore residue.

\section{Effect of ore / $\mathrm{NaOH}$ weight ratio:-}

A set of experiments has been performed using different $\mathrm{S} / \mathrm{R}$ (ore residue / $\mathrm{NaOH}$ ) ratio ranging from 1:1 to 1:4 while the other roasting conditions were fixed at $400{ }^{\circ} \mathrm{C}$ for $2 \mathrm{~h}$. The results plotted on Fig. (8) proved that the dissolution efficiency of $\mathrm{B}$ increased at $1 / 3$ ore $/ \mathrm{NaOH}$ ratio where $95.0 \%$ dissolution of $\mathrm{B}$ was acheived. Using $1 / 4 \mathrm{~S} / \mathrm{R}$ ratio decreases the leaching efficiency of $\mathrm{B}$ to $87.23 \%$. This most probably due to hydrolysis effect.

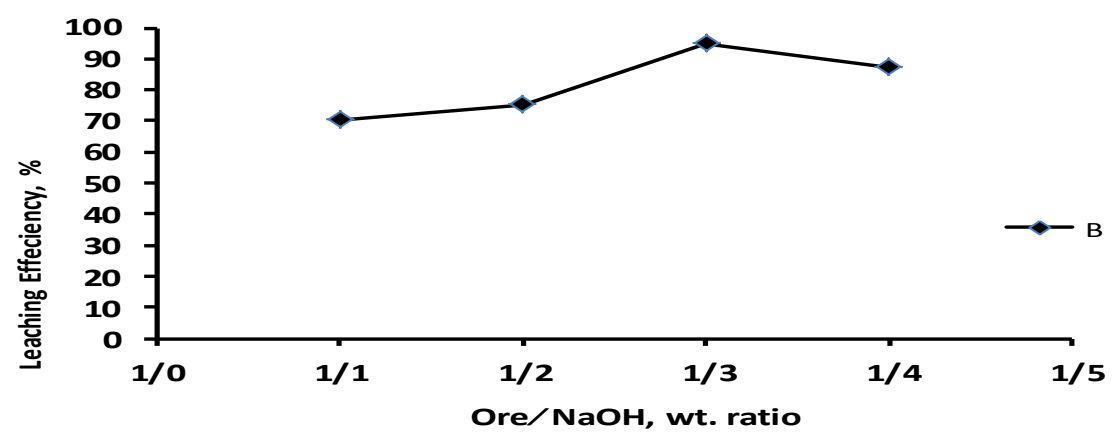

Fig. (8):- Effect of $\mathrm{NaOH}$ upon $\mathrm{B}$ dissolution efficiency of the working ore residue

\section{Effect of roasting time:-}

A set of roasting experiments was studied ranging from 1 to $3 \mathrm{~h}$. Other roasting conditions were fixed at an ore / $\mathrm{NaOH}$ ratio of $1: 3$ and roasting temperature of $400{ }^{\circ} \mathrm{C}$. The dissolution efficiency of B metal value is plotted in Fig. (9). From the results, it is clearly evident that increasing the fusion time from 1 to $2 \mathrm{~h}$ increases the dissolution efficiency of B till reached $95 \%$. Further increasing in the roasting time to 3 and $4 \mathrm{~h}$ has adversely affected the dissolution efficiency of $\mathrm{B}$, most probably due to hydrolysis effect.

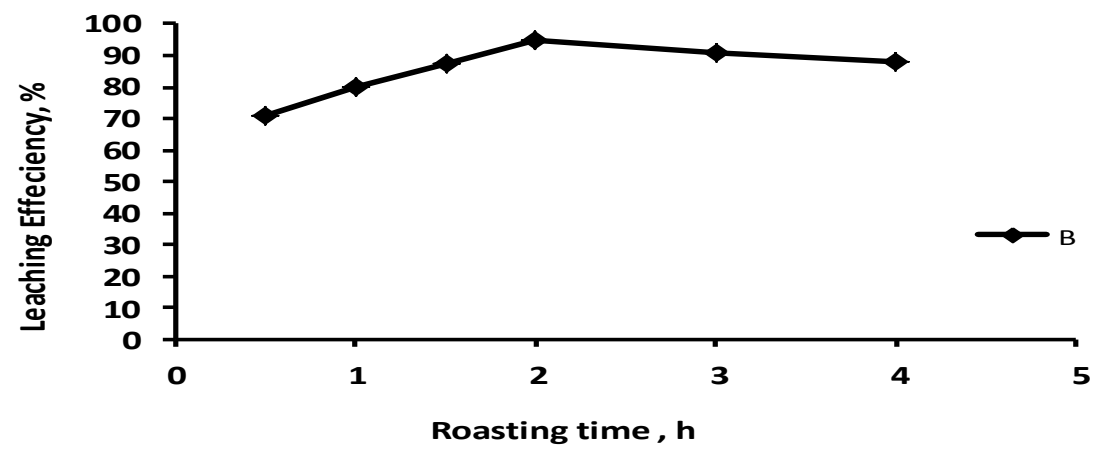

Fig. (9):- Effect of roasting time upon B efficiency of the working ore residue

\section{Effect of roasting temperature:-}

A series of roasting experiments has been studied at temperature ranging from $100{ }^{\circ} \mathrm{C}$ to $600^{\circ} \mathrm{C}$. Other roasting conditions were fixed at ore / $\mathrm{NaOH}$ ratio of 1:3 for $2 \mathrm{~h}$. The dissolution efficiency of $\mathrm{B}$, plotted in Fig. (10) indicated that increasing the roasting temperature to $400{ }^{\circ} \mathrm{C}$ increasing $\mathrm{B}$ dissolution to $95 \%$. These data indicated the roasting temperature is the most important factor for $\mathrm{B}$ dissolution. However, increasing the roasting temperature to 500 and $600{ }^{\circ} \mathrm{C}$ has an adverse effect on the dissolution efficiencies of $\mathrm{B}$ where the dissolution efficiency decreased to 92.22 and $85.88 \%$ respectively. This might be due to the formation of insoluble borosilicate compounds at high temperature which might be complicate its subsequent recovery (Vickand Whittle, 1969) ${ }^{(\mathbf{1 5})}$. This emphasized the association of boron with clay minerals (Abdellah, 2014) ${ }^{(\mathbf{1 6})}$. 


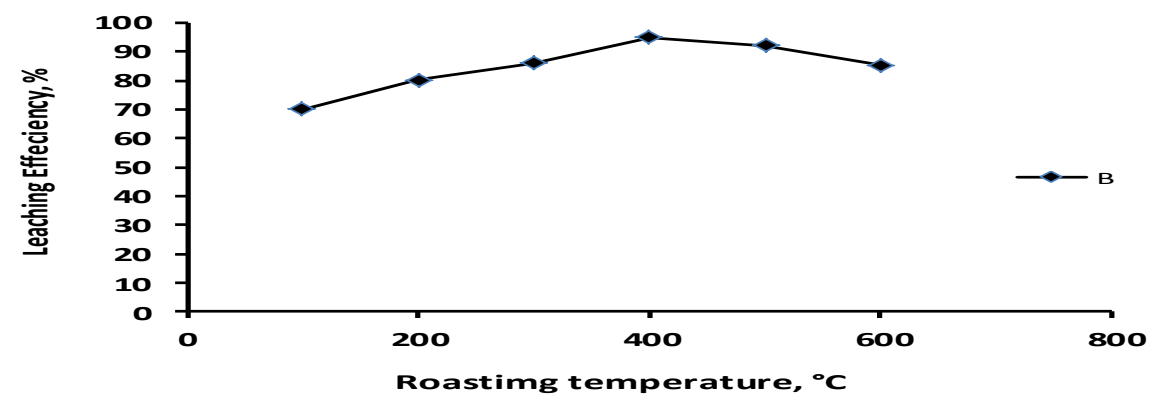

Fig. (10):- Effect of roasting temperature upon B of the working ore residue

In the light of the foregoing mentioned alkali roasting process of the working ore residue left, it can be concluded that, the optimum roasting conditions required for dissolving $95 \%$ of B was as following:
Ore / $\mathrm{NaOH}$, wt. ratio
$1: 3$
Roastingtime
$2 \mathrm{~h}$
Roasting temperature
$400^{\circ} \mathrm{C}$

After applying these optimal roasting conditions a proper pregnant leach liquor was prepared. The roasted matrix was then left to cool and leached with distilled water for $2 \mathrm{~h}$ at room temperature to bring out the dissolved boron. Accordingly, $500 \mathrm{~g}$ of the ore residue was used to yield 2 liters of alkaline leach liquor. The latter was found to assay $0.238 \mathrm{~g} / \mathrm{L}$ of $\mathrm{B}, 12.0 \mathrm{~g} / \mathrm{L}$ of $\mathrm{Si}$ and $39.2 \mathrm{~g} / \mathrm{L} \mathrm{Al}, 3.45 \mathrm{Cu}$ and $1.5 \mathrm{~g} / \mathrm{L} \mathrm{Zn}$ within $\mathrm{pH}$ value of $>12$.

\section{Recovery processes of silica and boron:-}

In this context, Amberlite IRA-743 anion exchange resin was used for B recovery. The latter has a macro porous poly-styrene matrix, on which N-methyl glutamine functional groups $\left(\mathrm{R}-\mathrm{N}\left(\mathrm{CH}_{3}\right)-\mathrm{C}_{6} \mathrm{H}_{8}(\mathrm{OH})_{5}\right)$ are attached as represented by fig. (11).

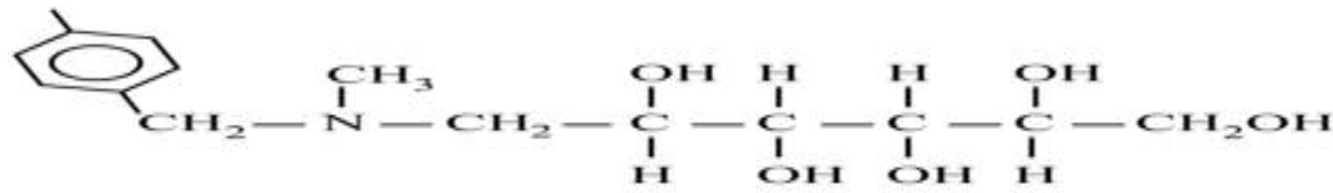

Fig. (11):- A scheme of building chemical structure of Amberlite IRA743

In the alkaline solution, boron was found in the anion species borates $\left[\mathrm{B}(\mathrm{OH})_{4}\right]^{-}$at $\mathrm{pH}$ value over 8 Muetterties $(\mathbf{1 9 6 7})\left({ }^{(17)}\right.$. The process of extraction depends upon the substitution reaction between the borate $\left[\mathrm{B}(\mathrm{OH})_{4}\right]^{-}$anions and anionic resin sites. Fig.(12) describe the mechanism of the uptake of boron from the aqueous solutions. The uptake of boron as borate anion $\mathrm{B}(\mathrm{OH})_{4}{ }^{-}$is a curious mechanism, where it involves protonation of the amine, deprotonation of the ploy sugar tail. Boric acid dissociate in distilled $\mathrm{H}_{2} \mathrm{O}$ to form the borate anion. While the protonation process of the amino group will be taken place as illustrated in equations below.

$$
\begin{aligned}
& \mathrm{B}(\mathrm{OH})_{3} \longrightarrow \mathrm{B}(\mathrm{OH})_{4}^{-}+\mathrm{H}^{+} \\
& \mathrm{CH}_{2}-\mathrm{N}-\mathrm{CH}_{2}-\mathrm{CH}_{2}^{-}+\mathrm{H}^{+} \longrightarrow-\mathrm{CH}_{2}-\mathrm{N}^{+} \mathrm{H}-\mathrm{CH}_{2}-\mathrm{CH}_{2}-
\end{aligned}
$$




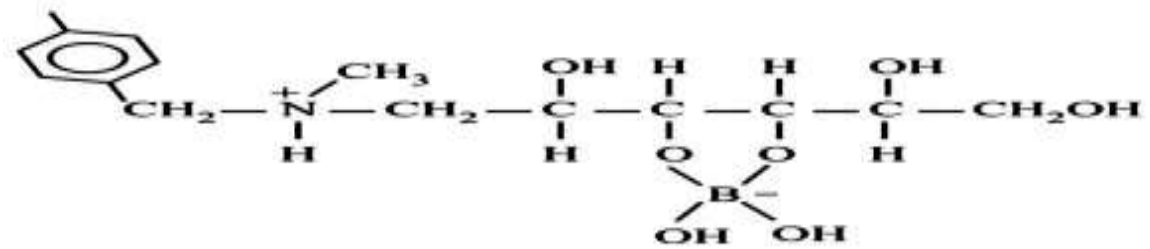

Fig. (12):- A scheme of boron uptake mechanism from the aqueous solutions

\section{Si-gel precipitation before loading of Boron:-}

Before applying the loading process of boron upon the resin, it is important to remove silica gel as by-product from the prepared alkaline leach liquor. The purpose is to avoid coating of the exchange sites of the resin. This was carried out by adjusting the $\mathrm{pH}$ value of the prepared alkali leach liquor via conc. $\mathrm{H}_{2} \mathrm{SO}_{4}$ to be 8.5. The precipitated silica in the form of $\mathrm{SiO}_{2}$-gel should be washed with dilute $\mathrm{H}_{2} \mathrm{SO}_{4}(1 \%)$ during filtration to avoid the loss of any dissolved boron by adsorption on its outer surface. The precipitate of $\mathrm{SiO}_{2}$-gel was then ignited at $850^{\circ} \mathrm{C}$ for $1 \mathrm{~h}$ and left to cool and then washed. After dryness, $\mathrm{SiO}_{2}$ was recovered with recovery efficiency up to $99 \%$, Fig. (13).

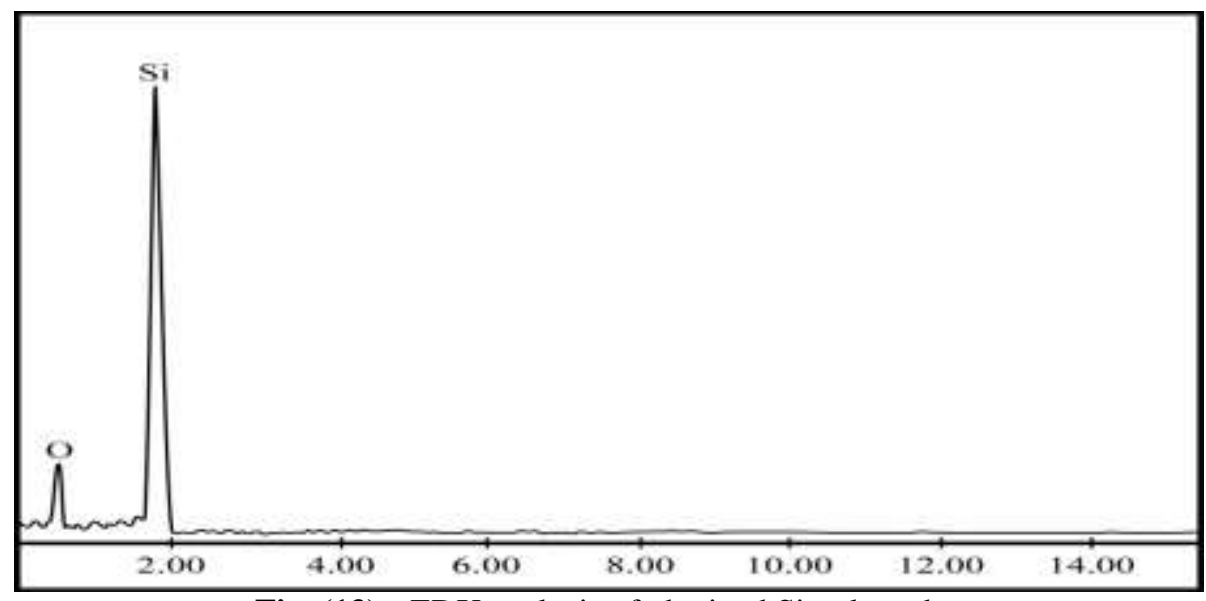

Fig. (13):- EDX analysis of obtained Si-gel product

\section{Loading process of boron:-}

In the present work, 2 Liters of the prepared leach liquor from $500 \mathrm{~g}$ residue left behind (mainly free from $\mathrm{SiO}_{2}$ ) was passed through the resin column packed with $79 \mathrm{ml}$ w.s.r at a working flow rate of $2 \mathrm{~mL} / \mathrm{min}$. The obtained effluents were collected every $100 \mathrm{~mL}$ for B analysis. From the obtained results (Fig. 14), it is evident that, the calculated capacity of the working resin for B represented about $68 \%$ and this is due to the competition of some anions in the resin sites especially $\mathrm{OH}^{-}$ions. Finally, the saturated resin was rapidly washed with distillated $\mathrm{H}_{2} \mathrm{O}$ to remove the remained amount of loaded species before applying the elution process.

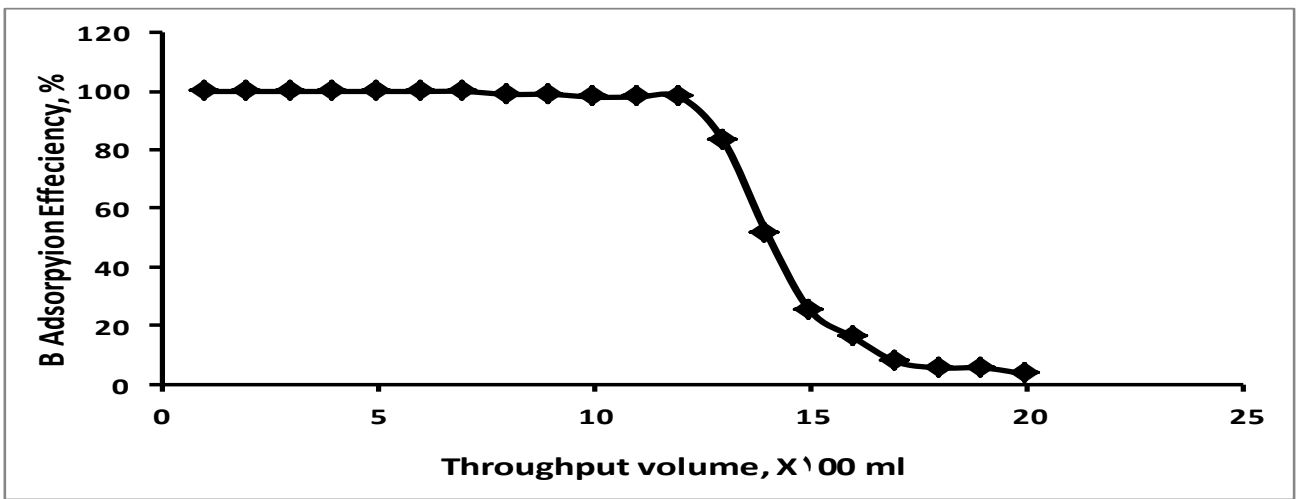

Fig. (14):- Adsorption curve of boron from alkaline leach liquor 


\section{Elution of the loaded boron:-}

Different elute solutions suggest good elution efficiencies for B e.g. dilute $\mathrm{HCl}, \mathrm{H}_{2} \mathrm{SO}_{4}$ and $\mathrm{NaOH}$. In the present work, the loaded Amberlite IRA743 was subjected to selective elution process of B by using hot $\mathrm{H}_{2} \mathrm{O}$ to regenerate $\mathrm{B}(\mathrm{OH})_{4}{ }^{-}$anion species depending upon the high solubility of borate ions in distilled water (Lahoda et al., 1995) ${ }^{(18)}$. The loaded resin when treated with hot $\mathrm{H}_{2} \mathrm{O}$ or very weak acid solution is being regenerated to its original structure as illustrated in the Fig. (15).

For this purpose, suitable volume of $100 \mathrm{~mL}$ hot distilled $\mathrm{H}_{2} \mathrm{O}$ was used at working flow rate of $1 \mathrm{~mL} / \mathrm{min}$ to remove almost loaded B. This is because, $\mathrm{B}(\mathrm{OH})_{4}{ }^{-}$anion species form slightly weak complexes with sorbitol hydroxyl groups of Amberlite IRA743.The eluate solution fractions each of 10mL bed volumes were collected to determine their boron content and to calculate the corresponding elution efficiency as plotted in Fig.(16).The obtained product was achieved through an evaporation process and then identified by means of XRD as shown in fig. (17).
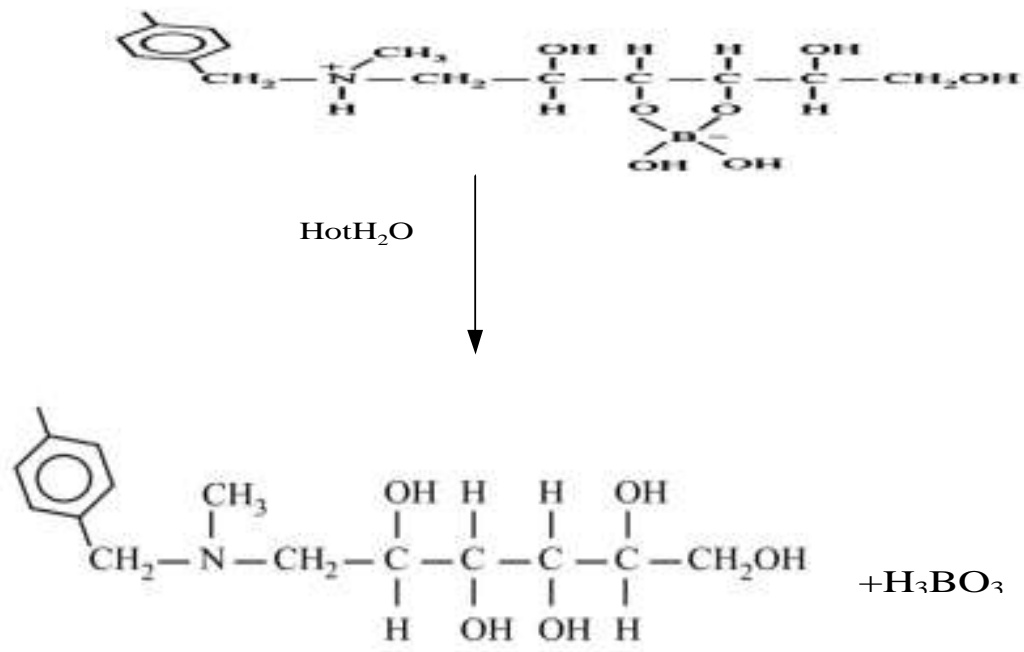

Fig. (15):- A Schematic diagram showing boron elution mechanism from the loaded resin.

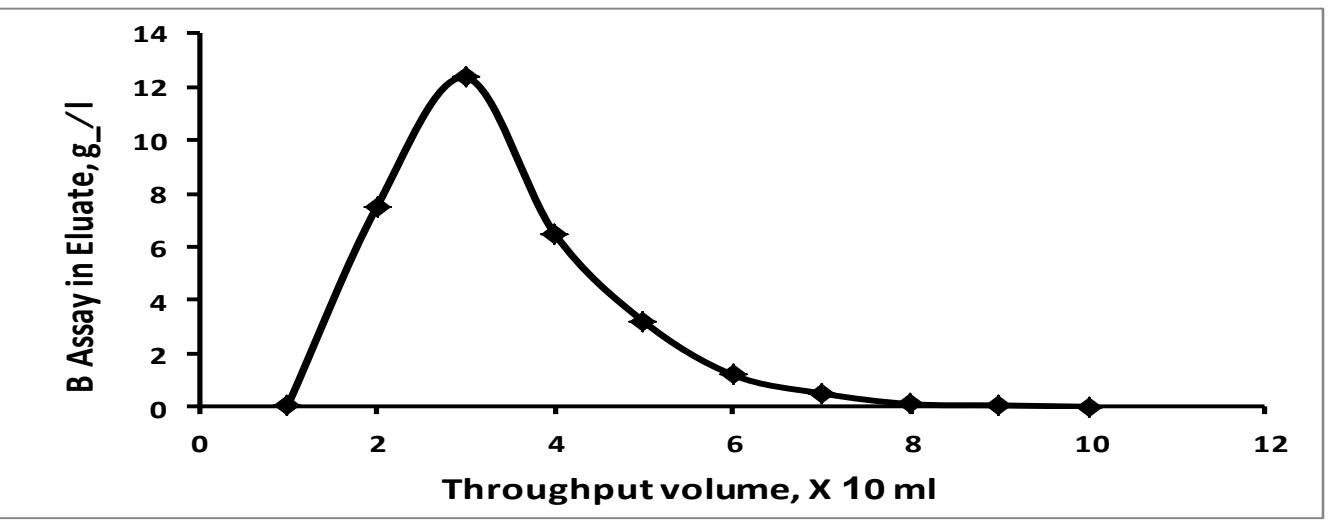

Fig.(16):- Boron elution curve of $40 \mathrm{ml}$ saturated Amberlite IRA 743resin bed 


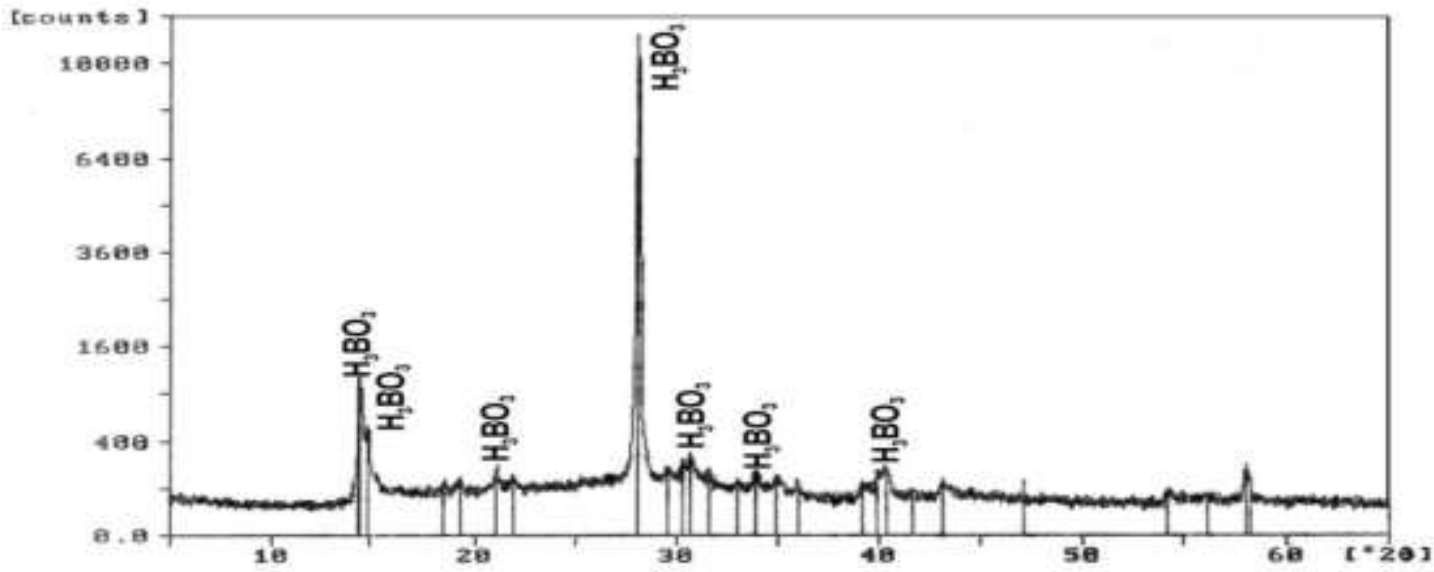

Fig. (17):- XRD pattern of obtained pure boric acid $\left(\mathrm{H}_{3} \mathrm{BO}_{3}\right)$.

\section{Conclusions:-}

$\mathrm{U}, \mathrm{REE}, \mathrm{Cu}, \mathrm{Zn}$ and $\mathrm{Al}$ leaching have been achieved upon their acidic leach liquor of the original raw ferruginous gibbsite-bearing shale of SW Sinai by using $\mathrm{H}_{2} \mathrm{SO}_{4}$ acid. The optimum leaching conditions were $200 \mathrm{~g} / \mathrm{L} \mathrm{H}_{2} \mathrm{SO}_{4}$; a solid/liquid ratio of $1 / 4,4 \mathrm{~h}$ and a particle size of -200 mesh, gave leaching efficiencies of about $100 \%$ for uranium and $88 \%$ for REEs, $68.57 \%$ for $\mathrm{Cu}, 66.52 \%$ forZn and $37.51 \%$ for $\mathrm{Al}$.

On the other hands, the remaining boron content which was left behind in the spent residue would be recovered via alkaline roasting process.From the two adequately obtained leach liquors, marketable products have conveniently been prepared.

\section{References:-}

1. Amer T.E.,(1997): Geochemistry and Extraction of U, $\mathrm{Cu}$ and $\mathrm{Mn}$ from the Ore Materials of the Uraniferous Paleozoic Sedimentary Rock, West Central Sinai, Egypt; Ph. D. Thesis, Fac. Sc., Cairo Univ., Cairo.

2. Mira, H. I. and Aita, S.K. (2009): Remobilization of uranium and copper through karstification processes; A case study in in Abu Thor locality, Um Bogma region, West Central Sinai, Egypt, Annals Geol. Surv. Egypt. , V.31, P. 21-42.

3. Amer, T.E., (1993): Physical and Chemical Studies on the U-Cu Mineralization of Uraniferous Paleozoic Sediments, West Central Sinai; M.Sc. Thesis, Fac. Sc., Cairo Univ., Cairo, 193 p.

4. Mahdy, M.A.,( 1995): Uranium, Copper and Manganese Recovery from sulphate Leach Liquor of West Central Sinai Uraniferous Siltstone. Egypt. J. Anal. Chem. 4.

5. Abdel Fattah, N.A., (2003): Uranium Extraction from Gibbsite-Bearing Sediments and Other Economic Elements by Using Solvents and Organic Compounds (Abu Zeneima Area, Sinai, Egypt). M.Sc. Thesis, Fac. Sc., Zagazig Univ., Egypt, 93.

6. El Hazek M.N., Ahmed F.Y, El Kasaby M.A. and Attia R.M. (2008): A Sulfuric acid leaching of polymetallic Abu Zeneima gibbsite-shale, Hydrometallurgy, V. 90, P. 34-39.

7. Ibrahim H.A. and El-Sheikh E. M (2011): Bioleaching Treatment of Abu ZeneimaUraniferous Gibbsite Ore Material for Recovering U, REEs, Al and Zn, Research Journal of Chemical Sciences, V. 1(4), p.55-66.

8. Shapiro L and Barnnock W.W., (1962); Rapid analysis of silicate, carbonate and phosphate rocks, U.S.Geol. Surv. Bull, 1114p.

9. Merritt, R. C. (1971): In the Extractive Metallurgy of Uranium; Merritt, R. C., Ed.; Colorado School of Mines Research Institute .

10. Preuss, A. F. and Kunin, R. (1958): Uranium Recovery by Ion Exchange; in Uranium Ore Processing by J. W. Clegg and D.D. Foley, Ed., Addison Wesley, Reading, Mass., USA.

11. Mathew K. J., Bürger S., Ogt S. V, Mason P.M.E.M. and Narayanan U. I., (2009):Uranium assay determination using Davies and Gray titration Proceedings of The Eighth International Conference on Methods and Applications of Radioanalytical Chemistry (Marc Viii) Kailua-Kona, Hawaii, 5.

12. Marczenko, Z. (1986): Separation andSpectrophotometric determination of elements, John Wiley and Sons, Harwood, New York. 
13. Aita, S.K. (1996): Geological, mineralogical and geochemical studies on some radioactive anomalies of the Paleozoic sediments of Um Bogma area, West Central Sinai, Egypt. M.Sc. Thesis, Cairo Univ., Egypt, 262p.

14. Habashi, F. (1993): A text book of hydrometallurgy; Metallurgi Extractive Quesbec, Canda, 689 p.

15. Vick, G. L. and Whittle, K. M., (1969): Solid Solubility and Diffusion: Coefficients of Boron in Silicon, Electrochememical Soc., V. 116, pp. 1142-1144.

16. Abdellah, W.M., Amer, T. E., Abdel Wahab, G. M. and AlShami, A. S., (2014): extraction of boron and vanadium from Abu Hamata alkali leach solution by using ion exchange resin, international journal of engineering research\&technology, V.3, P. 2033 - 2038.

17. Muetterties, E.L., (1967): The chemistry of boron and its compounds, New York: Wiley.

18. Lahoda, E.G., Battagli, J. A. and Impink, A.J., (2005): Boron isotopes separation by anion exchange chromatography, USA Patent P.44-732. 